\title{
Characterizing Wyoming Ranching Operations: Natural Resource Goals, Management Practices and Information Sources
}

\author{
Emily Kachergis ${ }^{1}$, Justin Derner ${ }^{1}$, Leslie Roche ${ }^{2}$, Kenneth Tate ${ }^{2}$, Mark Lubell ${ }^{3}$, Rachel Mealor ${ }^{4}$, \\ Jim Magagna ${ }^{5}$ \\ ${ }^{1}$ Rangeland Resources Research Unit, US Department of Agriculture-Agricultural Research Service, Cheyenne, USA; ${ }^{2}$ Department \\ of Plant Sciences, University of California, Davis, USA; ${ }^{3}$ Department of Environmental Science and Policy, University of California, \\ Davis, USA; ${ }^{4}$ University of Wyoming, Laramie, USA; ${ }^{5}$ Wyoming Stock Growers Association, Cheyenne, USA. \\ Email: Emily.Kachergis@gmail.com
}

Received November $17^{\text {th }}, 2012$; revised December $24^{\text {th }}, 2012$; accepted January $19^{\text {th }}, 2013$

\begin{abstract}
Spanning 12 million hectares, Wyoming rangelands produce food and provide other vital ecosystem services. However, the decision-making process of the ranchers who steward these lands is complex and poorly understood. In cooperation with the Wyoming Stock Growers Association (WSGA)—a predominant agricultural organization in the state-we asked WSGA producer members about their goals, ranching operation characteristics, and management practices via a mail survey. A total of 307 ranchers (50\%) responded to the survey. Livestock production and forage production were the top management goals, with ecosystem characteristics that support these goals (e.g., soil health, water quality) tied for second. Survey respondents' ranches had a median size of 4220 hectares, but ranged up to 185,000 hectares; $71 \%$ of operations included public land and $60 \%$ included private leased land. The majority of reporting operations grazed cow-calf pairs (91\%), with a median of 260 pairs per ranch. Most survey respondents managed grazing by moving 1 - 5 herds of livestock (84\%) among two or more pastures (92\%) after three months of grazing or less (87\%). Most operations (74\%) included other resource use activities, with extractive recreation (e.g., hunting; 55\%), conventional energy development (23\%), and other agricultural production (20\%) most common. Survey respondents primarily got information about grazing management from other ranchers (97\%), although they preferred to receive information through print publications (69\%). Wyoming ranching operations are diverse, which may represent a challenge for policy makers designing programs and incentives to increase production of food and ecosystem services. However, efforts that focus on livestock and forage production and supporting ecosystem functions are likely to find synergies with ongoing management goals and strategies. A multi-pronged outreach and education approach using several different media sources may be most effective as new policies and management practices become available.
\end{abstract}

Keywords: Beef Production; Ecosystem Services; Forage; Grazing; Livestock; Rangeland

\section{Introduction}

Rangelands have traditionally been managed to produce food and fiber from grazing animals. However, society expects additional ecosystem services from rangelands whose economic values are more difficult to measure, including clean water, wildlife habitat, and recreational opportunities [1,2]. Producing multiple benefits from rangeland ecosystems, and potentially increasing those benefits over time due to increasing demand, is a key challenge facing rangeland managers and policy makers [3-5].

The state of Wyoming has 12 million hectares of rangelands spanning two of the most extensive rangeland vegetation types in the US, sagebrush steppe and mixedgrass prairie. Wyoming beef cattle are an important source of food, worth over 600 million US dollars in 2012 [6]. Wyoming rangelands also produce a variety of additional ecosystem services, including wildlife habitat and recreational opportunities. Making up 50\% of Wyoming's lands, privately owned ranches are particularly important for providing these services. Private ranches maintain native ecosystems and open space [7] and over $90 \%$ of endangered species have habitat on private lands [8]. In fact, a Colorado study found that private ranches supported a greater diversity of native plants and birds than nature reserves within the same region [9]. However, 
the process by which private ranches produce these goods and services is complex. In 2007, about 3900 different ranching operations with over one million cattle grazed rangelands to achieve their goals in Wyoming alone [10].

Increasing demand for food and ecosystem services suggests that Wyoming rangelands may be expected to increase provision of multiple benefits in the future [2, 11]. Land management represents one avenue for increasing livestock production and ecosystem service provision. For example, ranchers and other land managers can use grazing and fire as tools to enhance wildlife habitat [12-14]. Policy is another key method of increasing the production of multiple benefits on rangelands. For example, US government programs such as the Conservation Reserve Program provide funding for implementation of management practices thought to provide conservation benefits, and development of new incentive programs is ongoing $[15,16]$. Education is a final means of increasing livestock production and ecosystem service provision. New information about practices and policies that promote these benefits can lead to management and policy actions [17].

Here, we describe the characteristics, goals, management practices, and information sources of Wyoming ranching operations in order to provide insight into producing livestock and providing ecosystem services on Wyoming rangelands. We conducted a mail survey of producer members of the Wyoming Stock Growers Association, a predominant agricultural organization in the state. This summary of survey results highlights linkages among food production and conservation, people and ecosystems on Wyoming rangelands. Survey findings will inform ranchers, other land managers, and the public about how Wyoming ranches are managing their lands to produce current quantities of livestock and ecosystem services. They will enable policy makers to design future programs and incentives for Wyoming ranchers to enhance rangeland benefits. Finally, they will guide educators and agricultural extension agents in distributing new knowledge of practices and programs.

\section{Methods}

We conducted the Rangeland Decision-Making Survey in January-March 2012 with the Wyoming Stock Growers Association (WSGA), the largest ranching organization in Wyoming. Mail surveys are a cost-effective way to obtain a large sample size, increasing the generalizability of results. The survey included sections of questions about "goals related to natural resource management," "operation information," "grazing practices on private land that is not irrigated," "grazing management practices," "personal history," and "information sources". As we aimed to learn about Wyoming ranchers, our sample frame was all producer members of the WSGA, who must be "growers of cattle, horses, mules or sheep." Survey implementation followed the Dillman Tailored Design method [18], including several survey announcements in October 2011-January 2012, a questionnaire mailed in January 2012, a postcard reminder in early February 2012, a replacement questionnaire in late February 2012, and additional legitimacy-building efforts via email and local media. Out of 749 WSGA producer members who received the survey, 81 indicated they were not part of the sample frame (e.g., did not currently own livestock) and were screened out. In all, 307 ranchers partially completed questionnaires and 281 ranchers completed over $80 \%$ of the questionnaire for a response rate of $49.6 \%$. Number of responses $(\mathrm{N})$ for each question ranges from 244 - 307 and is noted throughout.

We report different types of summary statistics for different types of survey questions. For open-ended questions (e.g., size of ranch and number of livestock), we report means, medians, and ranges. For multiple choice questions (e.g., other land management activities, information sources), we report the percentage of survey respondents who chose a particular answer. For the question about goals, where survey respondents were asked to rank a set of goals in order of the priorities of their operation, we report the average rank of each goal from 1 (highest priority) to 9 (lowest priority).

\section{Results}

\subsection{Wyoming Ranch Characteristics and Natural Resource Context}

Ranching operations spanned multiple ecosystems and land ownership types (Table 1; Figures 1 and 2). A majority of survey respondents grazed prairies/grasslands or sagebrush ecosystems, which are the major rangeland types in Wyoming (Figure 1). A smaller number grazed forests, mountain meadows, or riparian areas. Ranching operations most commonly included land owned by private individuals or groups ( $90 \% ; \mathrm{N}=303)$. Over half of operations (71\%; $\mathrm{N}=303$ ) also included land permitted or leased from the US government or the state of Wyoming, hereafter referred to as "public" land. Private leased land was also common (60\%; $\mathrm{N}=303)$. Public land grazing differed from private owned land grazing in several ways: a greater number of public lands contained grazing on sagebrush ( $66 \%$ vs. $54 \%$; $\mathrm{N}=272$ and 214 ) and forest lands ( $27 \%$ vs. $11 \%)$, and grazing was concentrated in the summer $(88 \% ; \mathrm{N}=214)$, whereas over a third of private owned land was grazed year-round (37\%; $\mathrm{N}=272$ ).

As is traditional in the western US (e.g. [19]), most ranches managed by survey respondents grazed cow/calf pairs (91\%; $\mathrm{N}=291)$, averaging 390 pairs per ranch (Table 1). About half as many ran stockers (129; 44\%), 
Table 1. General characteristics of Wyoming ranches based on the Wyoming Rangeland Decision-Making Survey (this study) and the National Agricultural Census [10].

\begin{tabular}{ccccc}
\hline \multirow{2}{*}{ Characteristic } & \multicolumn{2}{c}{ Rangeland decision-making survey $(\mathrm{N}=304)$} & $\begin{array}{c}\text { Wyoming operations with beef } \\
\text { cattle ranching and farming }{ }^{\mathrm{a}}[10]\end{array}$ \\
\cline { 2 - 4 } & Mean & Median & Range & Mean \\
\hline Total size (ha) & 11,120 & 4430 & $30-185,630$ & 2280 \\
Private owned (ha) & 3910 & 1860 & $0-50,590$ & - \\
Private leased (ha) & 1270 & 140 & $0-40,470$ & - \\
Public (ha) & 6030 & 690 & $0-141,640$ & 40 \\
Irrigated (ha) & 390 & 20 & $0-42,610$ & - \\
Irrigated percentage & $10 \%$ & $<1 \%$ & $0 \%-100 \%$ & $160^{\mathrm{b}}$ \\
Total livestock & 840 & 400 & $0-9000$ & - \\
Cow/calf pairs & 390 & 260 & $0-9000$ & $110^{\mathrm{c}}$ \\
Stockers & 270 & 0 & $0-8000$ & 40 \\
Other cattle (non-dairy) & - & - & $0-6500$ & - \\
Sheep & 170 & 0 & 0
\end{tabular}

a The agricultural operation category "beef cattle ranching and farming” is based on the predominant source of income and is part of the North American Indus-

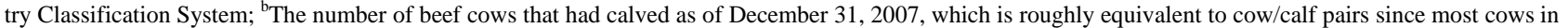
Wyoming calve soon after that date. This excludes heifers that had not calved, calves, steers, and bulls. This also excludes cows that summer in Wyoming but winter elsewhere; 'Other cattle include heifers that had not calved, calves, steers, and bulls as of December 31, 2007, and exclude dairy cows and beef cows that had calved. While it is likely that a majority of these could be classified as "stockers", this did not correspond directly to a question on the Wyoming Rangeland Decision-Making Survey.

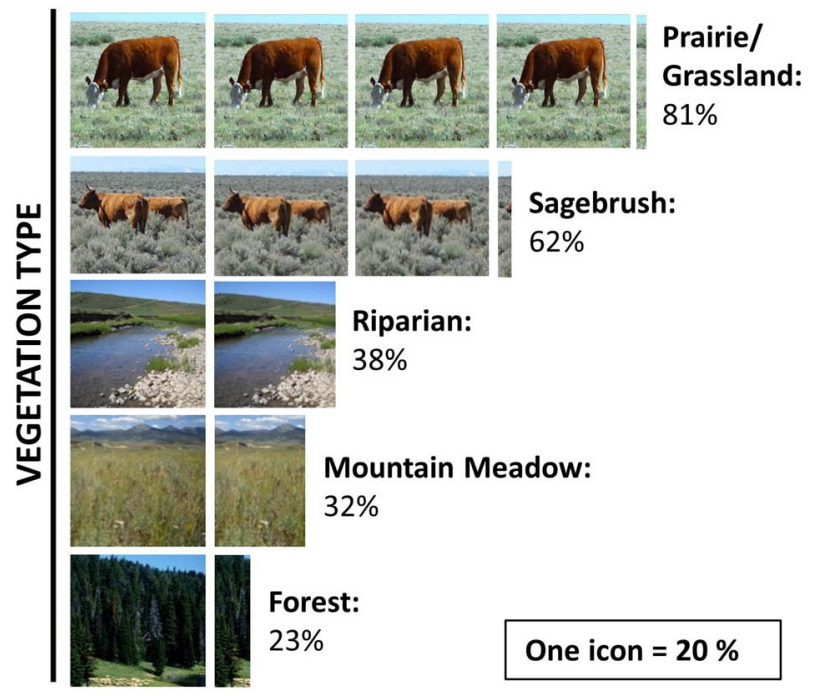

Figure 1. Percentage of Rangeland Decision-Making Survey respondents' Wyoming ranches that included each vegetation type $(\mathrm{N}=304)$. Photo credits (top to bottom): Justin Derner; Kirk Davies; Kira Puntenney; Emily Kachergis; Scott Bauer.

mostly in addition to cow/calf pairs (41\%). About one tenth $(12 \%$; $\mathrm{N}=291)$ ran sheep, also generally in addition to pairs $(12 \%)$. Five percent ran all three livestock types.

Other activities affected land management on almost three quarters of survey respondents' ranches (74\%; $\mathrm{N}=$ 291; Figure 3). Extractive recreation such as hunting and fishing was most common, occurring on over half of operations (55\%).
A comparison of survey respondents and Wyoming livestock producers represented by the National Agricultural Census $[6,10]$ helps put survey findings in context (Table 1). Survey respondents were located in every Wyoming county, with a minimum of 3 (1\%; Uinta) and a maximum of 21 (8\%; Albany) from each, similar to the relatively even distribution of agricultural operations throughout Wyoming according to the agricultural survey [6]. Survey respondents had more land and livestock than beef cattle ranching and farming operations in the 2007 Wyoming agricultural census [10]; (Table 1). The many possible reasons for this include differences between the survey methodologies (e.g., land leased on a per-AUM basis is not counted by [10]) and ranchers' motivations for joining WSGA. Large operations (greater than 100 head) contribute almost $90 \%$ of the beef cattle inventory in Wyoming [6], highlighting the importance of WSGA producer members represented by this survey for managing Wyoming rangelands.

\subsection{Management Goals}

Livestock and forage production were survey respondents' top two management goals, with average ranks of 1.8 and 2.0 (Figure 4; $\mathrm{N}=284$ ) out of nine possible goals listed on the survey. Ecosystem characteristics that can directly support forage and livestock production, including riparian and/or meadow health (rank 4.6), soil health (rank 4.7), invasive plants (rank 4.7), and water quality (rank 5.0), formed a second tier of closely ranked goals. Recreation (rank 6.8), carbon sequestration (rank 

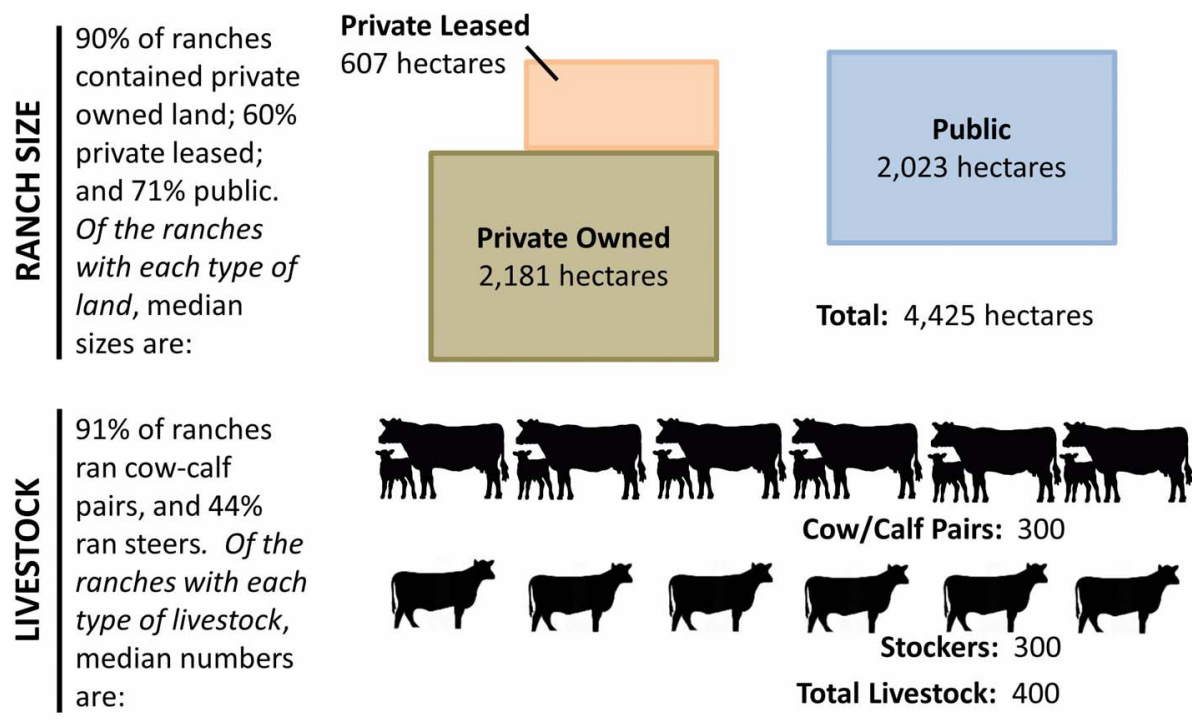

Figure 2. Median ranch characteristics of survey respondents' ranches. Medians are reported within ranches that have a particular type of land ownership or livestock.

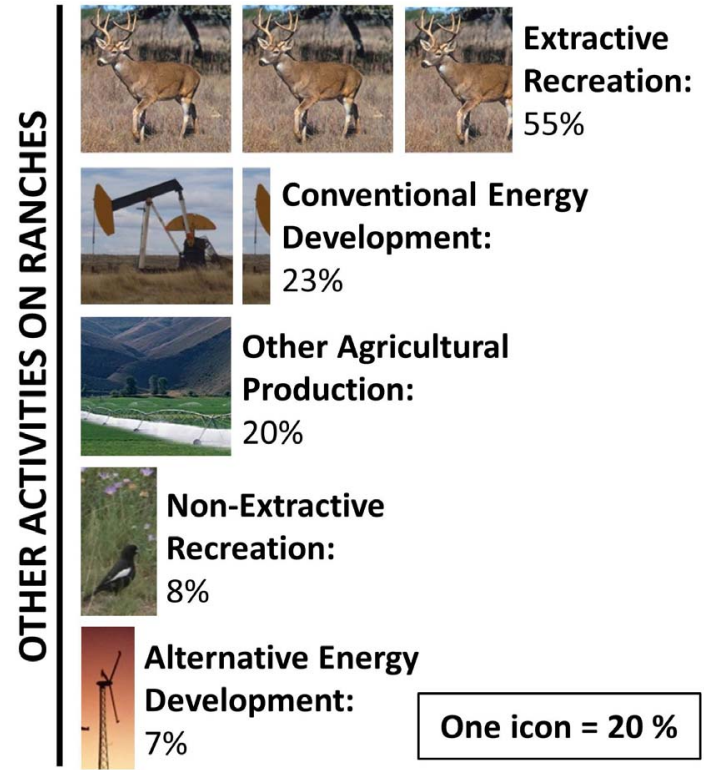

Figure 3. Percentage of survey respondents' ranches that include other activities affecting land management. Photo credits (top to bottom): Scott Bauer; Julie Reeves (USFWS); Jack Dykinga; David Augustine; Scott Bauer.

7.0), and wildlife (rank 7.3) trailed behind the others. Ranks varied from 1 - 9 for all goals except forage production and livestock production, which ranged from rank $1-8$, and carbon sequestration, which ranged from 4 - 9 .

\subsection{Grazing and Natural Resource Management}

Most ranches had one to five herds of livestock (1: 29\%; 2 - 5: 55\%; 6 - 10: 8\%; >10: 8\%; $\mathrm{N}=287$ ), which were rotated to a different pasture after three months of graz-

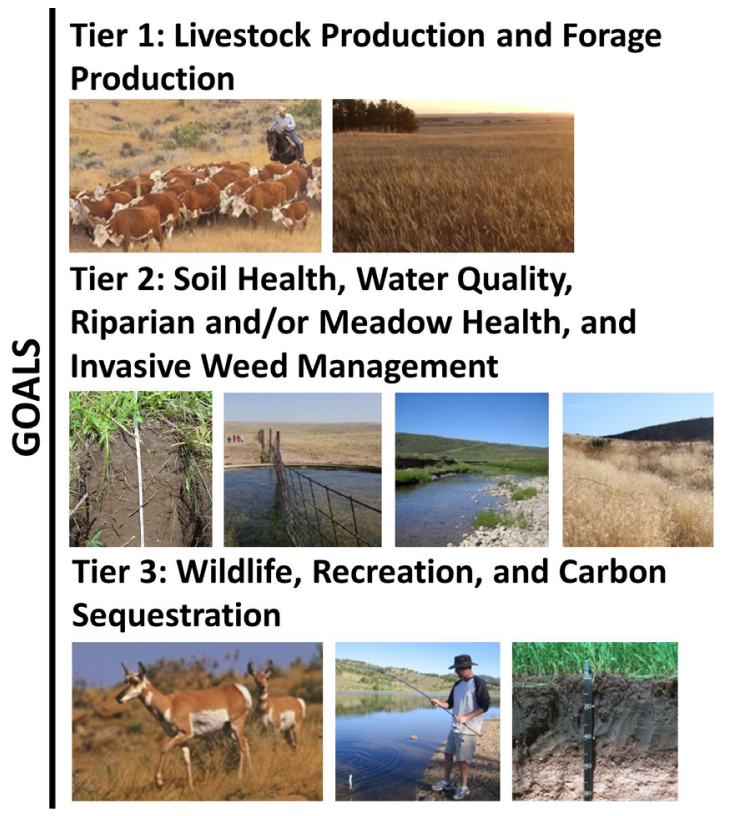

Figure 4. Survey respondents' management goals. Photo credits (top left to bottom right): Jack Dykinga; Emily Kachergis; Emily Kachergis; Emily Kachergis; Kira Puntenney; Jaepil Cho; Jack Dykinga; Julie Reeves (USFWS); Unknown (USDA-ARS).

ing or less (three months or less: 87\%; year-long or season-long grazing: 13\%; $N=291$; Figure 5). Most ranches had multiple pastures, with almost a third having more than 10 pastures (1: 8\%; 2 - 5: 38\%; 6 - 10: 25\%; >10: $30 \%$; N = 288; Figure 5). Pastures were rested at some point during the year (99\%; $\mathrm{N}=280$ ), but timing was variable, as was season of grazing. Stock density varied, but few ranches grazed at more than 20 hectares per animal unit $(6 \% ; \mathrm{N}=285)$. 


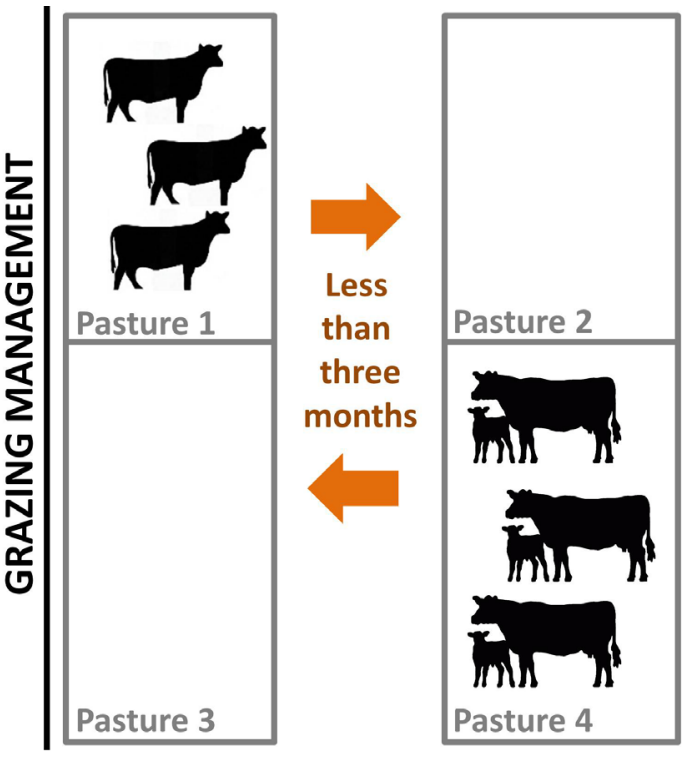

Figure 5. Grazing management practices on survey respondents' ranches. Most ranches had one to five herds of livestock which were rotated through multiple pastures after less than three months of grazing.
In addition to grazing management, survey respondents used a variety of practices to achieve their goals (Table 2; Figure 6). Over two-thirds of survey respondents used each of four broad categories of management practices: herd management (98\%), facilities (96\%), vegetation management (90\%), and landscape enhancements (69\%; $N=279)$. Creating a supplemental feeding plan, matching genetics and calving season to local conditions, developing livestock drinking water, and consulting a veterinarian on a herd health plan were rated as the most key practices for achieving goals (Table 2; Figure 6). The most often-used vegetation management practices were grazing livestock and using herbicides to change plant species composition. The most often-used landscape enhancement was restoring meadows and wetlands.

A majority of survey respondents monitor vegetation ( $70 \%$ on private land, $60 \%$ on public or state land; $\mathrm{N}=$ 289 and 268), even without participating in programs that require monitoring. A smaller percentage monitor vegetation as part of a program that requires monitoring (13\% on private land; $18 \%$ on public land). About one-fifth do

Table 2. Management practices used to support natural resource goals on survey respondents' ranches. Within each category (e.g., FACILITIES), practices are listed in descending order according to the proportion of ranchers who use them.

\begin{tabular}{|c|c|c|c|c|c|c|}
\hline \multirow{3}{*}{ Management practices } & \multirow{3}{*}{$\mathrm{N}$} & \multicolumn{4}{|c|}{ Have you used this practice in the last five years? } & \multirow{3}{*}{$\begin{array}{l}\text { Additional information would be useful for } \\
\text { future management decisions }\end{array}$} \\
\hline & & \multicolumn{3}{|c|}{ Yes. Related to goals, it is... } & \multirow{2}{*}{ No } & \\
\hline & & Key & Helpful & Not effective & & \\
\hline \multicolumn{7}{|l|}{ FACILITIES } \\
\hline Livestock drinking water development & 279 & $68 \%$ & $22 \%$ & $1 \%$ & $9 \%$ & $35 \%$ \\
\hline Cross fencing to create more small pastures & 275 & $35 \%$ & $39 \%$ & $7 \%$ & $19 \%$ & $21 \%$ \\
\hline Livestock exclosure development & 244 & $6 \%$ & $28 \%$ & $11 \%$ & $55 \%$ & $18 \%$ \\
\hline Livestock trail development & 250 & $2 \%$ & $19 \%$ & $16 \%$ & $63 \%$ & $10 \%$ \\
\hline \multicolumn{7}{|l|}{ VEGETATION MANAGEMENT } \\
\hline Use herbicides to change plant species & 269 & $17 \%$ & $44 \%$ & $6 \%$ & $32 \%$ & $26 \%$ \\
\hline Graze livestock to change plant species & 263 & $16 \%$ & $41 \%$ & $7 \%$ & $36 \%$ & $28 \%$ \\
\hline Use fire to change plant species & 262 & $10 \%$ & $29 \%$ & $7 \%$ & $54 \%$ & $17 \%$ \\
\hline Use equipment to change plant species & 257 & $7 \%$ & $28 \%$ & $8 \%$ & $57 \%$ & $18 \%$ \\
\hline Plant non-native plant species & 259 & $3 \%$ & $28 \%$ & $8 \%$ & $61 \%$ & $20 \%$ \\
\hline Plant native plant species & 261 & $5 \%$ & $28 \%$ & $5 \%$ & $62 \%$ & $20 \%$ \\
\hline Land clearing-remove all woody species & 265 & $8 \%$ & $24 \%$ & $6 \%$ & $62 \%$ & $14 \%$ \\
\hline \multicolumn{7}{|l|}{ LANDSCAPE ENHANCEMENTS } \\
\hline Restore meadows and wetlands & 261 & $17 \%$ & $30 \%$ & $5 \%$ & $48 \%$ & $18 \%$ \\
\hline Establish wildlife habitat & 260 & $12 \%$ & $36 \%$ & $5 \%$ & $47 \%$ & $20 \%$ \\
\hline Stabilize streambeds & 259 & $14 \%$ & $28 \%$ & $6 \%$ & $53 \%$ & $15 \%$ \\
\hline Create riparian buffer & 261 & $9 \%$ & $23 \%$ & $6 \%$ & $62 \%$ & $15 \%$ \\
\hline \multicolumn{7}{|l|}{ HERD MANAGEMENT } \\
\hline Match calving season to local conditions & 276 & $61 \%$ & $32 \%$ & $<1 \%$ & $7 \%$ & $21 \%$ \\
\hline Supplemental feeding plan & 271 & $51 \%$ & $39 \%$ & $2 \%$ & $7 \%$ & $27 \%$ \\
\hline Match genetics to local conditions & 272 & $56 \%$ & $35 \%$ & $<1 \%$ & $10 \%$ & $23 \%$ \\
\hline Consult a veterinarian on herd health plan & 275 & $53 \%$ & $36 \%$ & $<1 \%$ & $10 \%$ & $24 \%$ \\
\hline Synchronize breeding & 265 & $19 \%$ & $26 \%$ & $7 \%$ & $48 \%$ & $12 \%$ \\
\hline
\end{tabular}




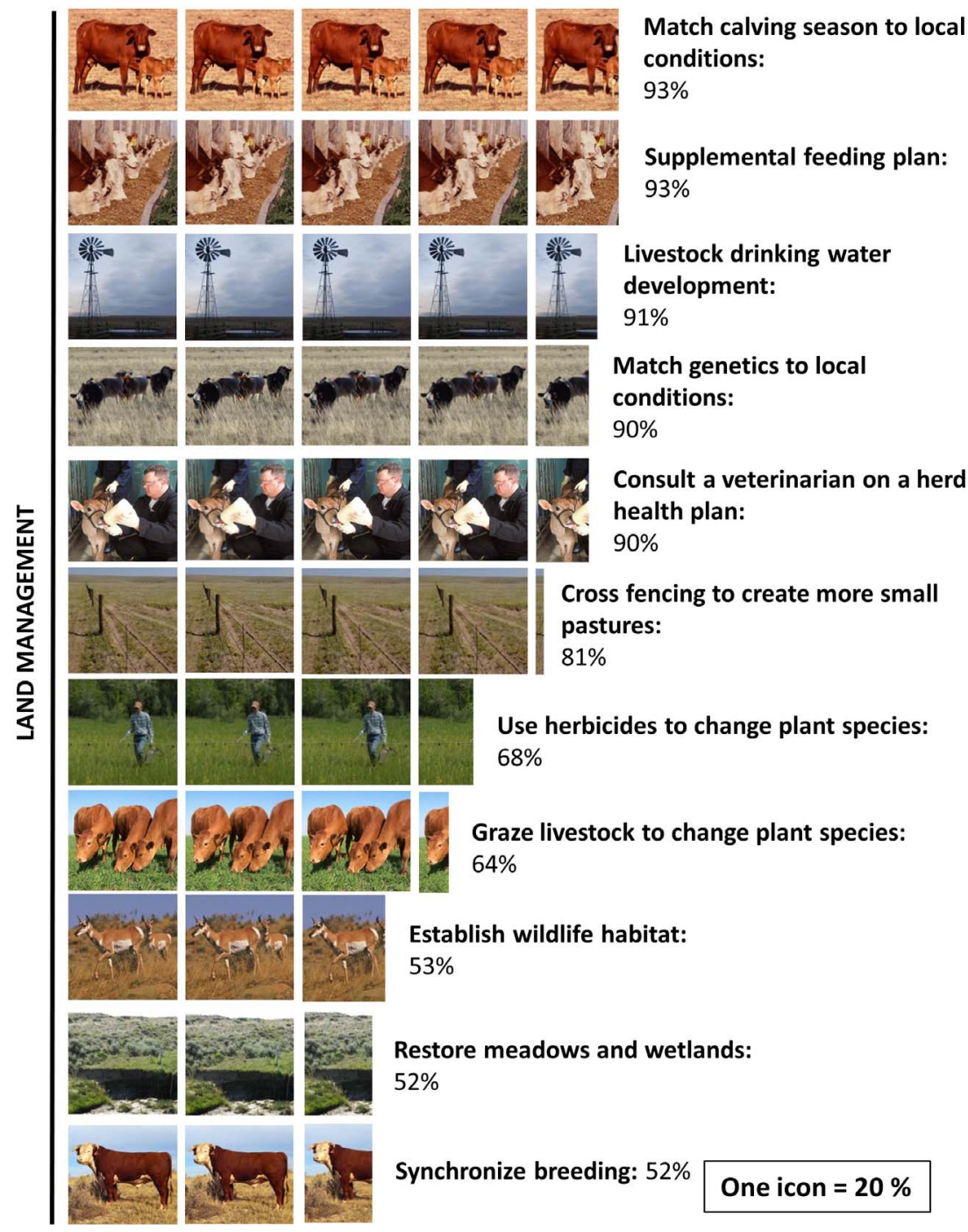

Figure 6. Popular land management practices and the percentage of survey respondents who used them. Photo credits (top to bottom): Emily Kachergis; Scott Bauer; Brian Prechtel; Justin Derner; Stephen Ausmus; Emily Kachergis; Rachel Mealor; Stephen Ausmus; Jack Dykinga; John Likins; Michael MacNeil.

not monitor vegetation ( $17 \%$ on private land; $22 \%$ on public land).

\subsection{Information Sources}

Other ranchers were the most often-used and highly rated source of information about ranching (Table 3), with Wyoming Weed and Pest and Wyoming Stock Growers Association next in line. Conservation Districts, University of Wyoming Extension, and the Natural Resource Conservation Service also ranked highly.

Internet access is improving across Wyoming, and may represent a growing avenue for producers to receive information about ranching. A majority of survey respondents accessed the internet via high-speed connections $(75 \%$; $\mathrm{N}=304)$, with fewer connecting via smartphone (9\%) and dial-up (4\%). About $18 \%$ did not have internet access $(\mathrm{N}=304)$. Frequency of internet access varied widely (Figure 7). The survey respondent was the primary user of the internet to access information related to ranching (56\%; $N=267$ ). Even though many of them had internet access, a majority of survey respondents preferred to receive information about ranching through print publications (69\%; $\mathrm{N}=303$ ) rather than the internet (21\%) or word of mouth (27\%).

\subsection{Socio-Economic Background}

Most survey respondents were men (89\%; $\mathrm{N}=297)$ with a mean age of 62 (range $21-94 ; \mathrm{N}=294$ ) who have lived most of their lives in rural regions $(89 \% ; \mathrm{N}=303)$. Over three-quarters of survey respondents' families have been ranching for three or more generations (three: 31\%; four: $30 \%$; five: $18 \%$; $N=298$ ). Survey respondents also 
Table 3. Use and quality of different sources of information about ranching, according to survey respondents.

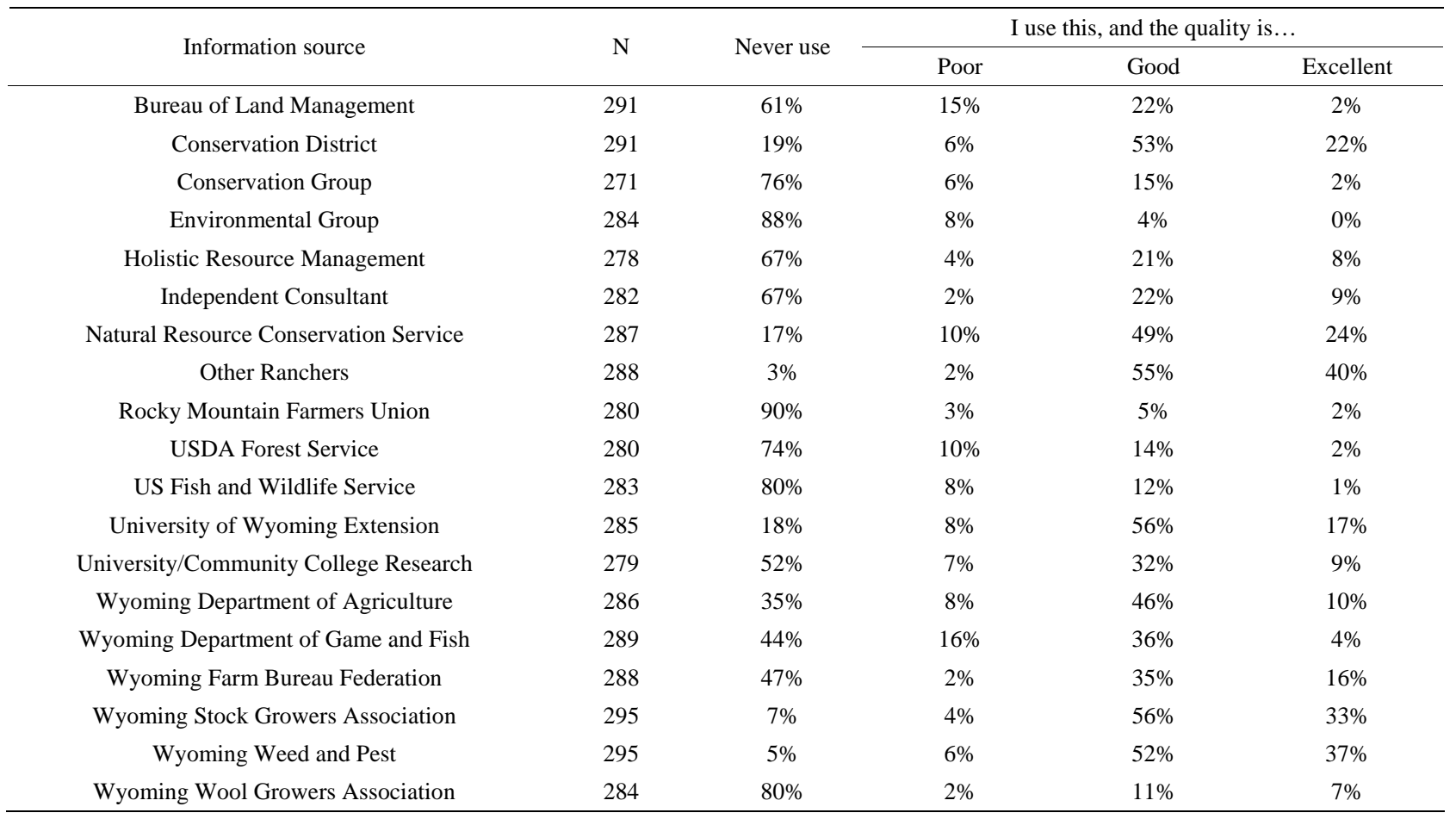

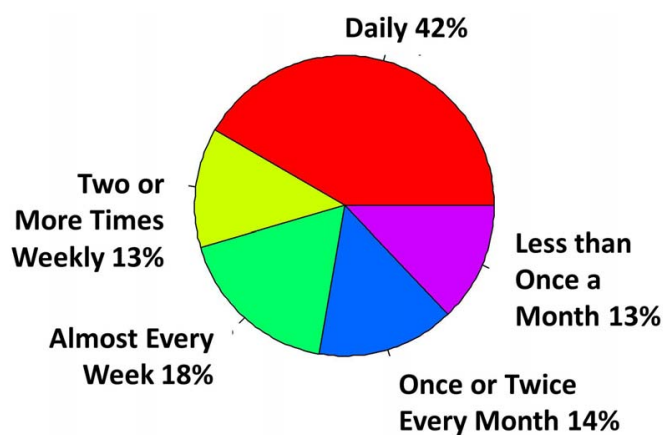

Figure 7. Frequency of internet access, among the $82 \%$ of survey respondents who had internet access $(\mathrm{N}=261)$.

had some college education or beyond (83\%; $\mathrm{N}=302)$. The most interesting part of ranching to survey respondents was animal husbandry (Figure 8), with range management and economics and business management following behind that. Almost all ranches had some kind of off-ranch income (82\%; $\mathrm{N}=299$ ), including off-ranch employment (31\%), oil and gas development (24\%), and stock market investments (24\%).

Almost half of survey respondents had a succession plan that identified a strategy for keeping their land in ranching in the future $(47 \% ; \mathrm{N}=282)$. Twenty-three percent of respondents were working on a plan, and $24 \%$ did not have a succession plan. The remainder either did not own private land $(4 \%)$ or indicated that the status of their succession plan was not captured by these options (1\%).

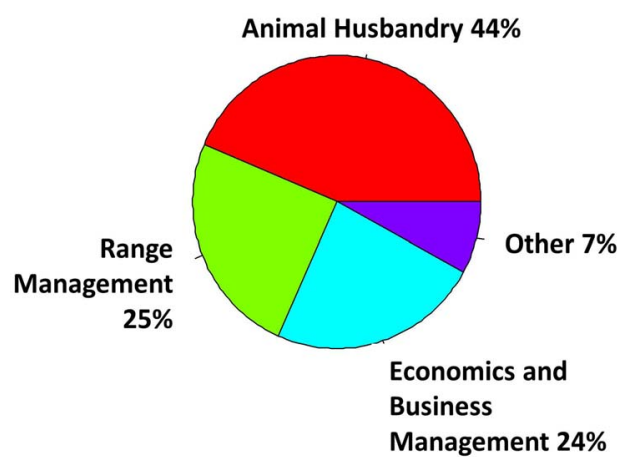

Figure 8. The most interesting part of ranching to survey respondents $(\mathrm{N}=299)$.

\section{Discussion: Balancing Livestock Production and Provision of Ecosystem Services on Wyoming Rangelands}

The Wyoming Rangeland Decision-Making Survey showed that producer members of the Wyoming Stock Growers Association manage diverse operations, with a mix of land ownership, vegetation types, land use, and livestock (Table 1; Figures 1-3). Ranch sizes ranged from 30 to nearly 200,000 hectares, and the maximum number of livestock was 9000 (Table 1). Other surveys have also shown that ranches in the western US are very diverse, making it difficult to define a typical ranch [19-21]. Despite their diversity, this survey showed some commonalities in survey respondents' ranching operations and their management. Most ranches 1) consisted of multiple 
land ownership types (including public land); 2) grazed cow-calf pairs; and 3) incorporated other activities that affect land management [19-22]. These general characteristics can guide future efforts to balance livestock production and provision of ecosystem services. For example, the diversity of land ownership and activities on individual ranches implies that partnerships among multiple landowners, public land managers, and other stakeholders may be increasingly necessary for integrated production and conservation efforts $[7,23]$.

Survey respondents manage natural resources with the goals of producing livestock and preserving the ecosystem characteristics that support livestock production, such as forage production and soil health. Similarly, ranchers in Utah and western Colorado said that livestock production and conservation of natural resources were their main goals influencing their decision-making [24,25]. Colorado ranchers also emphasized "the link between those goals" [25; p. 333]. Combined, these studies suggest that efforts to produce ecosystem services on rangelands that focus on livestock and forage production and supporting ecosystem functions are most likely to find synergies with ongoing management goals and strategies. For example, land managers and policy makers can choose livestock grazing in addition to other practices to try to enhance ecosystem services, as some ranchers and conservation groups are doing [26]. Similarly, efforts to restore the productivity of degraded ecosystems are consistent with ranchers' goals.

Survey respondents' grazing management and other land management practices emphasized livestock production but also included efforts to improve the condition of natural resources. As with operation characteristics, management practices were diverse, but we highlight several commonalities. Grazing management generally involved a less than three-month rotation through multiple pastures and incorporated rest (Figure 5), similar to other American and Australian ranching operations [19, $27,28]$. Water development and fencing were additional important management practices that facilitate rotational grazing (Figure 6). In Australia, Ash and Stafford-Smith [29] noted an increase in the frequency of these practices and suggested that their precise use can increase livestock production. Herd management practices related to animal health, also common in Utah and Australia $[19,28]$, can also help improve livestock production. Two broad categories of natural resource management practices, vegetation management and landscape enhancements, were used by over two-thirds of survey respondents. In a longitudinal survey of landowners of California oak woodlands, Huntsinger et al. [22] found that use of oak woodland and wildlife habitat conservation practices had increased over 19 years. Our survey results and trends in other rangeland regions of the western US sug- gest that many ranchers use management practices to provide ecosystem services that are synergistic with livestock production.

New information about managing rangelands for livestock production and ecosystem services is constantly becoming available, and is especially important given the high turnover of ranch land ownership in Wyoming and the western US in recent years [30,31]. Other ranchers and several organizations, notably WSGA and Wyoming Weed and Pest, were often-used and highly-regarded sources of information about ranching. However, survey respondents preferred to receive information about ranching from print publications rather than by word of mouth or over the internet. Even though the internet is not the preferred way of communicating, the fact that a majority of ranchers have internet access suggests that it will be an important avenue for sharing information about rangeland management in the future. A multi-pronged approach to outreach and education using several different media sources may be most effective [31].

\section{Conclusion}

The Wyoming Rangeland Decision-Making Survey described the characteristics, goals, management practices, and information sources of survey respondents' ranching operations and provided several insights into balancing livestock production and provision of ecosystem services on Wyoming rangelands. First, Wyoming ranching operations are diverse in operation characteristics and management practices, which may represent a challenge for policy makers who are designing programs and incentives to increase provision of ecosystem services. However, the survey also identified several shared characteristics that can guide these efforts. Ranchers' goals suggest that efforts that focus on livestock and forage production and supporting ecosystem functions are likely to complement ongoing management. Future research on the management practices that ranchers use should identify the many synergies between livestock production and ecosystem service provisioning as well as the trade-offs, where acceptable [3]. As new policies and management practices become available, a multi-pronged outreach and education approach using several different media sources may be most effective.

\section{Acknowledgements}

We would like to thank the WSGA membership and staff whose participation made this project possible. The Rangeland Decision-Making Survey and related work was funded by a grant from the Western Sustainable Agriculture, Research, and Education program (Project Number SW10-073). 


\section{REFERENCES}

[1] K. M. Havstad, D. P. C. Peters, R. Skaggs, J. R. Brown, B. T. Bestelmeyer, E. L. Fredrickson, J. E. Herrick and J. Wright, "Ecological Services to and from Rangelands of the United States,” Ecological Economics, Vol. 64, No. 2, 2007, pp. 261-288. doi:10.1016/j.ecolecon.2007.08.005

[2] Millenium Ecosystem Assessment, "Ecosystems and Human Well-Being: Synthesis,” World Resources Institute, Washington DC, 2005.

[3] D. D. Briske, "Rangeland Conservation Effects Assessment Project Executive Summary: The Next Generation of Conservation Practice Standards," Conservation Effects Assessment Program Review, USDA Natural Resources Conservation Service, Washington DC, 2011.

[4] J. H. Goldstein, G. Caldarone, T. K. Duarte, D. Ennaanay, N. Hannahs, G. Mendoza, S. Polasky, S. Wolny and G. C. Daily, "Integrating Ecosystem-Service Tradeoffs into Land-Use Decisions," Proceedings of the National Academy of Sciences of the United States of America, Vol. 109, No. 19, 2012, pp. 7565-7570. doi:10.1073/pnas.1201040109

[5] E. Nelson, G. Mendoza, J. Regetz, S. Polasky, H. Tallis, R. Cameron, K. M. Chan, G. C. Daily, J. Goldstein, P. M. Kareiva, E. Lonsdorf, R. Naidoo, T. H. Ricketts and R. Shaw, "Modeling Multiple Ecosystem Services, Biodiversity Conservation, Commodity Production, and Tradeoffs at Landscape Scales," Frontiers in Ecology and the Environment, Vol. 7, No. 1, 2009, pp. 4-11. doi:10.1890/080023

[6] USDA NASS, "Wyoming 2012 Agicultural Statistics," USDA National Agricultural Statistics Service, Cheyenne, 2012.

[7] M. W. Brunson and L. Huntsinger, "Ranching as a Conservation Strategy: Can Old Ranchers Save the New West?” Rangeland Ecology \& Management, Vol. 61, No. 2, 2008, pp. 137-147. doi:10.2111/07-063.1

[8] United States General Accounting Office, “Endangered Species Act: Information on Species Protection on Nonfederal Lands,” 1994.

http://www.gpo.gov/fdsys/pkg/GAOREPORTS-RCED-9 5-16/pdf/GAOREPORTS-RCED-95-16.pdf

[9] J. D. Maestas, R. L. Knight and W. C. Gilgert, "Biodiversity across a Rural Land-Use Gradient," Conservation Biology, Vol. 17, No. 5, 2003, pp. 1425-1434. doi:10.1046/j.1523-1739.2003.02371.x

[10] USDA NASS, "Wyoming State and County Data, 2007 Census of Agriculture,” USDA National Agricultural Statistics Service, Cheyenne, 2007.

[11] P. K. Thornton, "Livestock Production: Recent Trends, Future Prospects," Philosophical Transactions of the Royal Society of London: Series B, Biological Sciences, Vol. 365, No. 1554, 2010, pp. 2853-2867. doi:10.1098/rstb.2010.0134

[12] J. D. Derner, W. K. Lauenroth, P. Stapp and D. J. Augustine, "Livestock as Ecosystem Engineers for Grassland Bird Habitat in the Western Great Plains of North America,” Rangeland Ecology \& Management, Vol. 62, No. 2, 2009, pp. 111-118. doi:10.2111/08-008.1
[13] D. J. Augustine and J. D. Derner, "Disturbance Regimes and Mountain Plover Habitat in Shortgrass Steppe: Large Herbivore Grazing Does Not Substitute for Prairie Dog Grazing or Fire,” The Journal of Wildlife Management, Vol. 76, No. 4, 2012, pp. 721-728. doi:10.1002/jwmg.334

[14] S. R. Archer, K. W. Davies, T. E. Fulbright, B. McDaniel, B. Wilcox and K. I. Predick, "Brush Management as a Rangeland Conservation Strategy: A Critical Evaluation,” Conservation Effects Assessment Program Review, USDA Natural Resources Conservation Service, Washington DC, 2011.

[15] K. L. Olenick, U. P. Kreuter and J. R. Conner, "Texas Landowner Perceptions Regarding Ecosystem Services and Cost-Sharing Land Management Programs," Ecological Economics, Vol. 53, No. 2, 2005, pp. 247-260. doi:10.1016/j.ecolecon.2004.09.016

[16] S. Engel, S. Pagiola and S. Wunder, "Designing Payments for Environmental Services in Theory and Practice: An Overview of the Issues,” Ecological Economics, Vol. 65, No. 4, 2008, pp. 663-674. doi:10.1016/j.ecolecon.2008.03.011

[17] P. Kristjanson, R. S. Reid, N. Dickson, W. C. Clark, D. Romney, R. Puskur, S. Macmillan and D. Grace, "Linking International Agricultural Research Knowledge with Action for Sustainable Development," Proceedings of the National Academy of Sciences of the United States of America, Vol. 106, No. 13, 2009, pp. 5047-5052. doi:10.1073/pnas.0807414106

[18] D. A. Dillman, "Mail and Internet Surveys: The Tailored Design Method,” John Wiley \& Sons, Hoboken, 2007.

[19] D. L. Coppock and A. H. Birkenfeld, "Use of Livestock and Range Management Practices in Utah," Journal of Range Management, Vol. 52, No. 1, 1999, pp. 7-18. doi:10.2307/4003486

[20] D. L. Coppock, "Ranching and Multiyear Droughts in Utah: Production Impacts, Risk Perceptions, and Changes in Preparedness," Rangeland Ecology \& Management, Vol. 64, No. 6, 2011, pp. 607-618. doi:10.2111/REM-D-10-00113.1

[21] R. C. Rowan and L. D. White, "Regional Differences among Texas Rangeland Operators,” Journal of Range Management, Vol. 47, No. 5, 1994, pp. 338-343. doi:10.2307/4002326

[22] L. Huntsinger, M. Johnson and M. Stafford, "A Resurvey of Oak Woodland Landowners: 1985, 1992, and 2004,” Proceedings of the 6th Symposium on Oak Woodlands: California's Oaks, Today's Challenges, Tomorrow's Opportunities,” Rohnert Park, 9-12 October 2006, pp. 57-67.

[23] R. R. J. McAllister, N. Abel, C. J. Stokes and I. J. Gordon, "Australian Pastoralists in Time and Space: The Evolution of a Complex Adaptive System,” Ecology and Society, Vol. 11, No. 2, 2006, p. 41.

[24] C. A. Kennedy and M. W. Brunson, "Creating a Culture of Innovation in Ranching: A Study of Outreach and Cooperation in West-Central Colorado," Rangelands, Vol. 29, No. 3, 2007, pp. 35-40. doi:10.2111/1551-501X(2007)29[35:CACOII]2.0.CO;2

[25] E. A. Didier and M. W. Brunson, "Adoption of Range Management Innovations by Utah Ranchers,” Rangeland 
Ecology \& Management, Vol. 57, No. 4, 2004, pp. 330336.

doi:10.2111/1551-5028(2004)057[0330:AORMIB]2.0.C $\underline{\mathrm{O} ; 2}$

[26] S. D. Fuhlendorf and D. M. Engle, "Application of the Fire-Grazing Interaction to Restore a Shifting Mosaic on Tallgrass Prairie,” Journal of Applied Ecology, Vol. 41, No. 4, 2004, pp. 604-614.

[27] C. W. Hanselka, A. McGinty, B. S. Rector, R. C. Rowan and L. D. White, "Grazing and Brush Management on Texas Rangelands: An Analysis of Management Decisions," Texas Agricultural Extension Service, College Station, 1990.

[28] G. Bortolussi, J. G. McIvor, J. J. Hodgkinson, S. G. Coffey and C. R. Holmes, "The Northern Australia Beef Industry, a Snapshot. 4. Condition and Management of Natural Resources,” Australian Journal of Experimental
Agriculture, Vol. 45, No. 9, 2005, pp. 1109-1120. doi:10.1071/EA03262

[29] A. J. Ash, and D. M. Stafford Smith, "Pastoralism in Tropical Rangelands: Seizing the Opportunity to Change," The Rangeland Journal, Vol. 25, No. 2, 2003, pp. 113127. doi:10.1071/RJ03010

[30] H. Gosnell, J. H. Haggerty and W. R. Travis, "Ranchland Ownership Change in the Greater Yellowstone Ecosystem, 1990-2001: Implications for Conservation,” Society \& Natural Resources, Vol. 19, No. 8, 2006, pp. 743-758. doi:10.1080/08941920600801181

[31] R. D. Mealor, P. J. Meiman, A. L. Hild, D. T. Taylor and J. S. Thompson, "New Rangeland Residents in Wyoming? A Survey of Exurban Landowners," Rangeland Ecology \& Management, Vol. 64, No. 5, 2011, pp. 479-487. doi:10.2111/REM-D-09-00120.1 